\title{
Dialysis therapy, 2020 year in review 8. 心血管領域
}

\author{
藤㟝 毅一郎 ${ }^{1}$ 常 喜 信彦 ${ }^{2}$ 新田 孝 作 $^{3}$ \\ 1 飯塚病院腎臟内科 2 東邦大学医療センター大橋病院腎臟内科 \\ 3 東京女子医科大学第四内科学講座
}

2020 年に出版された透析患者と血清カリウム值に 関する文献について, 第66回日本透析医学会学術集会 の学術委員会企画「Dialysis therapy, 2020 year in review」で提示した，本稿では，発表した論文 4 編に ついて概説する。

\section{I ．腹膜透析と低カリウム血症}

Davies ら ${ }^{1)} は$, Peritoneal Dialysis Outcomes and Practice Patterns Study（PDOPPS；2014 2017 年) に参加した 7 か国から 18 歳以上の PD 患者 (7,421 人) を対象とした前向きコホート研究を行った．主要評価 項目は, 全死亡および腹膜炎発症とし, ベースライン の患者抢よび治療因子とその後の血清カリウム值が低 值（ $<4 \mathrm{mEq} / \mathrm{L} ）$ であることとの関連を検討した．対 象を $\mathrm{K}$ 值で 5 分位に分け, ロジスティック回帰法で評 価した. $4 \mathrm{mEq} / \mathrm{L}$ 未満の $\mathrm{K}$ 值は総死亡, 腹膜炎発症 に有意な関連はなかったが，観察期間中に $4 \mathrm{mEq} / \mathrm{L}$ 未満の $\mathrm{K}$ 值が 4 回観察されたことは総死亡リスクに有 意に関連していた（図 1)。また，今回同時に検討され た $4 \mathrm{mEq} / \mathrm{L}$ 末満の $\mathrm{K}$ 值と腹膜炎発症の起炎菌は有意 な関連はなかった。低 K 血症はグラム陰性菌による感 染のリスク因子であるとの報告があるが，今回の検討 では腹膜炎と消化管由来の感染との関連性は得られな かった.

\section{II 、食事によるカリウム摂取}

Romos $5^{2}$ ) は保存期 CKD 患者 (95 名, 中央值年齢 67 歳, $32 \%$ が糖尿病, 推定系球体滤過量中央值 $23 \mathrm{~mL} /$ $\left.\min / 1.73 \mathrm{~m}^{2}\right)$ と $\mathrm{HD}$ 患者 (117 名, 年齢中央值 39 歳, $50 \%$ が糖尿病）を対象とした，それぞれの 3 日間の食 事調查を行いカリウム摂取, カロリー摂取状況を把握 する横断研究を行った，評価項目は，血清カリウム值
および高カリウム血症とした。保存期 CKD と HD 患 者の正常 $\mathrm{K}$ 群, 高 $\mathrm{K}$ 血症群両群ともカリウム摂取量は 多くなく, カリウム摂取量は血清カリウム值, 高カリ ウム血症どちらにも関連していなかった。また，保存 期 $\mathrm{CKD}, \mathrm{HD}$ 患者どちらに抏いても，糖尿病は高 $\mathrm{K}$ 血 症のリスク因子であり，それぞれのオッズ比は 3.55 (95\%Cl 1.07-11.72)，4.22（95\%Cl 1.31-13.6）であっ た。この点に関しては, 低アルドステロン症とRAS 阻 害薬使用者が糖尿病患者, CKD 患者に多く, 高 $\mathrm{K}$ 血 症となりやすい患者背景が推察された。

\section{III．血液透析患者におけるPatiromer使用の効果}

Amdur ら ${ }^{3)}$ は, 導入後 90 日以上経た無尿である血 液透析患者（18 歳以上 70 歳以下）で $\mathrm{K}$ 值が試験開始 前 3 か月で 2 回 $5.1 \mathrm{mEq} / \mathrm{L}$ 以上となった 27 名の患者 を対象に Patiromerを用いた非無作為オープンラベ ル・クロスオーバー試験（単一施設）を行った。 Patiromer は消化管で吸収されないカリウム吸着性ポリ マーで，ナトリウムを含まず，消化管内で $\mathrm{Ca}$ と K を 交換し，最終的には便中に排泄される薬剤である。評 価項目は, Patiromer 使用 12 週後の $\mathrm{K}$ 值の変化とし た。試験期間中の透析処方と食事による $\mathrm{K}, \mathrm{Ca}, \mathrm{Mg}$, $\mathrm{P}$ の摂取量は一定であった $(\mathrm{Na}$ の摂取量は有意に減少 した）。試験期間中， $42 \%$ の患者で $\mathrm{K}$ 值は 3.5 5.0 $\mathrm{mEq} / \mathrm{L}$ の範囲に維持された(図 2). Patiromer 内服中 は $\mathrm{K}$ 便中排泄が増加していた(図 3)。血液透析患者で は，Patiromer 内服は血清 $\mathrm{K}$ 值を低下させ，短期的な 高 $\mathrm{K}$ 值血症の有効な治療となる可能性がある.

\section{ICU における持続的腎代替療法（CRRT） と血清 $P, K$ 値}

Cho ら ${ }^{4)}$ は, 2015 年 1 月〜 2018 年 12 月の間に急性

藤㠃 毅一郎 飯塚病院腎臓内科 $\bar{\top} 820-8505$ 福岡県飯塚市芳雄町 3-83

Kiichiro Fujisaki Tel: 0948-22-3800 Fax：0948-29-7029 
a

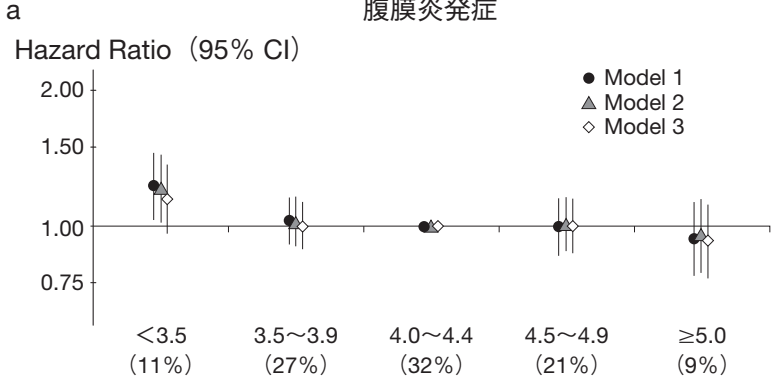

Average serum $\mathrm{K}_{\text {prior-4mo }}, \mathrm{mEq} / \mathrm{L}$

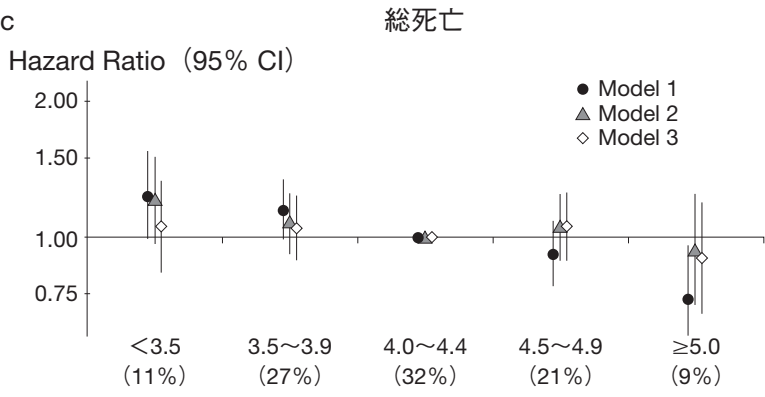

Average serum $\mathrm{K}_{\text {prior-4mo, }}, \mathrm{mEq} / \mathrm{L}$ b

Hazard Ratio $(95 \% \mathrm{Cl})$

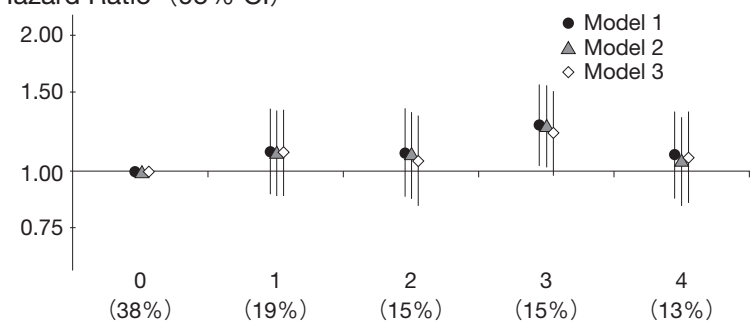

Number of months with serum $\mathrm{K}<4 \mathrm{mEq} / \mathrm{L}$

総死亡と $\mathrm{K}$ 值 $<4 \mathrm{mEq} / \mathrm{L}$ の回数

Hazard Ratio (95\% Cl)

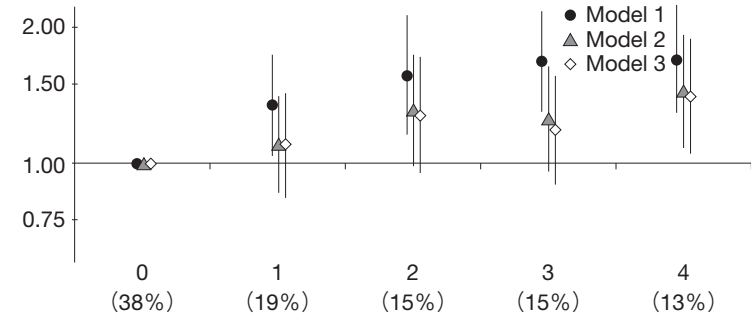

Number of months with serum $\mathrm{K}<4 \mathrm{mEq} / \mathrm{L}$

図 1 死亡と腹膜炎に対する血清 $\mathrm{K}$ 值の関連

Model 1: 国籍, Model 2: 国籍, 性・年齢, 透析歴, その他 13 要因, Model 3：Model 2+K 調整因子（文献 1 より引用）
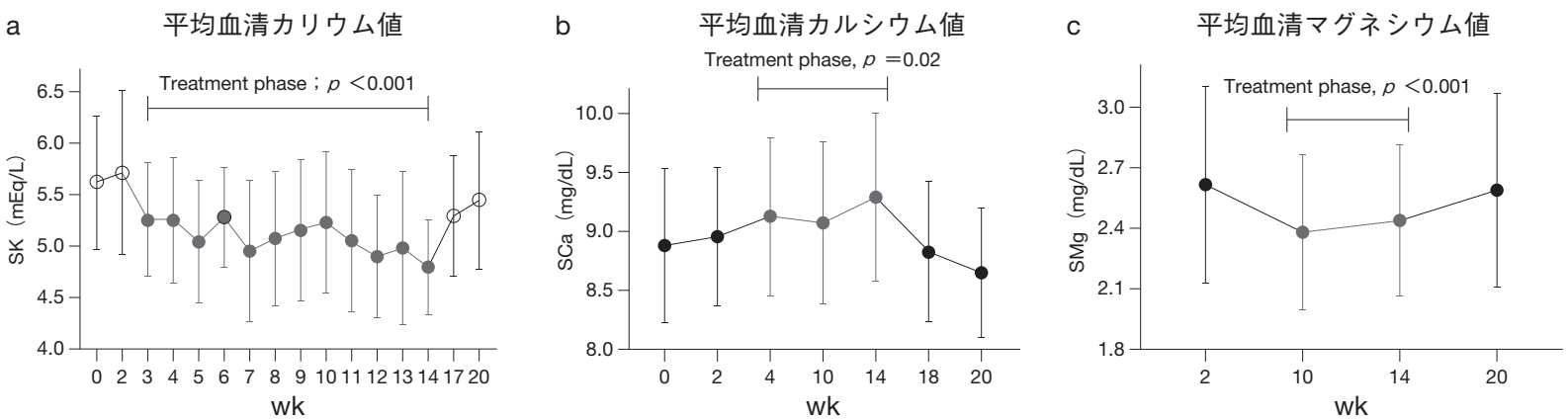

図 2 血清濃度の変化

(文献 3 より引用)
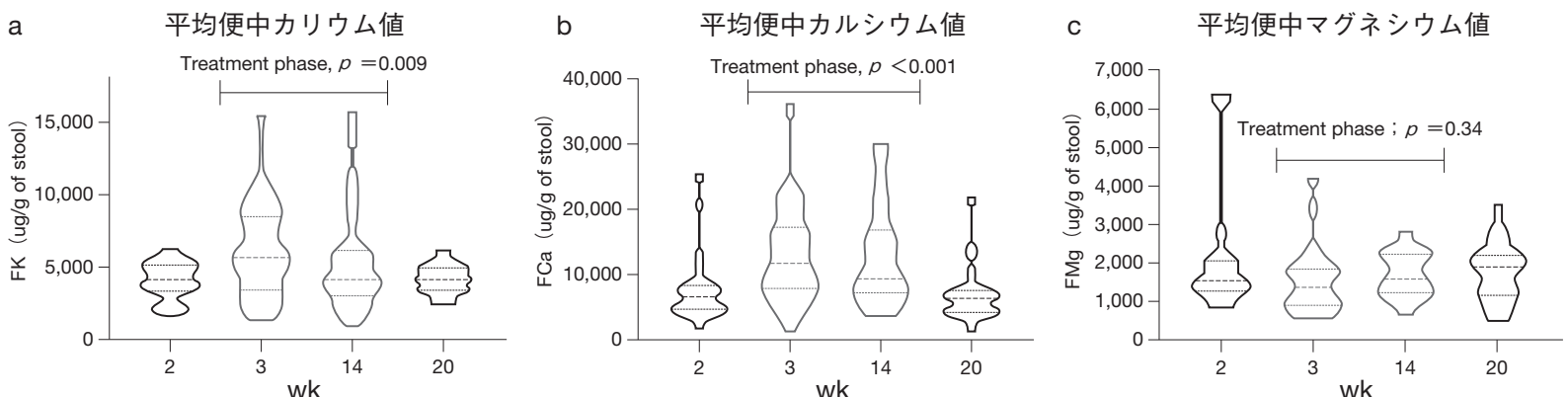

図 3 便中排泄の変化

(文献 3 より引用)

腎障害を発症した ICU 入室患者を対象に後ろ向きコ ホート研究を行った. 3 種類の異なった CRRT の透析 液を使用し，患者の血清 $\mathrm{P}$ 值および $\mathrm{K}$ 值を評価した。 CKD 患者や間歇的に HD を必要としていた患者は除
外された。

評価項目は，血清 $\mathrm{P}$ 值，血清 $\mathrm{K}$ 值低下の抑制とし た．血液流量は $150 \mathrm{~mL} / \mathrm{min}$, 透析液および補充液の 流量は $2,000 \mathrm{~mL} / \mathrm{min}$, 除水はその患者個々の状態に 
合わせて設定した.

第 1 群 $(2015$ 年 1 月 1 日 2016 年 6 月 30 日)：透析 液と補充液の両方に Hemosol B0（K, P なし）を使用 した。第 2 群 (2016 年 7 月 1 日〜2017 年 7 月 12 日)： Hemosol B0 と MultiBic (K $4 \mathrm{mmol} / \mathrm{L})$ を使用した。 第 3 群 (2017 年 7 月 13 日〜 2018 年 12 月 30 日) Phoxilium (K, P 含有), Hemosol B0, Prismasol 2 (K 2 $\mathrm{mmol} / \mathrm{L})$ および Prismasol 4 (K $4 \mathrm{mmol} / \mathrm{L})$ を使用 した. ICU 入室後の死亡率は, 各群間で有意な差はな かった（1 群: 51.4\%, 2 群: 37.2\%, 3 群 : 48.9\%, $p=$ 0.131). 3 群間のリン酸塩およびカリウムの補充の有 無については，第 1 群では 105 人中 62 人 $(59.1 \%), 2$ 群では 78 人中 36 人 $(46.2 \%), 3$ 群では 141 人中 16 人 (11.4\%) であったＩCUにおける CRRTでは，Kお よび $\mathrm{P}$ 含有透析液を使用することで低 $\mathrm{K}$ 血症, 低 $\mathrm{P}$ 血 症を予防することができ，K，P の静脈補充を減少さ せた。

\section{文献}

1) Davies SJ, Zhao J, Morgenstern H, et al. Low serum potassium levels and clinical outcomes in peritoneal dialysis-international results from PDOPPS. Kidney Int Rep 2020； 6: 313-24.

2) Romos CI, González-Ortiz A, Espinosa-Cuevas A, Avesani CM, Carrero JJ, Cuppari L. Does dietary potassium intake associate with hyperkalemia in patients with chronic kidney disease? Nephrol Dial Transplant 2020 [Online ahead of print]

3) Amdur RL, Paul R, Barrows ED, et al. The potassium regulator patiromer affects serum and stool electrolytes in patients receiving hemodialysis. Kidney Int 2020; 98: 1331-40.

4) Cho AJ, Lee YK, Park HC. Impact of electrolyte-rich dialysate during continuous renalreplacement therapy on serum phosphate and patassium in ICU patients. PLoS One 2020； 15：e0238867. 